\title{
IMPACT OF HEAVY METALS ON MORPHOLOGICAL AND BIOCHEMICAL PARAMETERS OF Shorea robusta PLANT
}

\author{
PREETI PANDEY PANT, A.K. TRIPATHI
}

Ecology \& Environment Division Forest Research Institute, P.O. New Forest, Dehradun, 248006, Uttarakhand, India; e-mail: preeti.fri@gmail.com,tripathiak@icfre.org

\begin{abstract}
Pant P.P., Tripathi A.K.: Impact of heavy metals on morphological and biochemical parameters of Shorea robusta plant. Ekológia (Bratislava), Vol. 33, No. 2, p. 116-126, 2014.

A study was conducted to determine the impact of heavy metals (cadmium [Cd], arsenic [As] and lead $[\mathrm{Pb}]$ ) on the morphological, and biochemical parameters of Shorea robusta and to investigate the uptake capacity of this plant for individual heavy metal. The study showed that all three heavy metals had significant adverse impact on most of the plant parameters of S. robusta, at all the given concentrations of 1,5 and $10 \mathrm{mg} / \mathrm{l}$. Maximum reduction in morphological parameters is observed in leaf area (92.67\%) followed by shoot length (54\%) and, root length $(28.78 \%)$. Maximum reduction in biochemical parameters is observed in amino acid (75.13\%) followed by chlorophyll (68.33\%) and, crude protein (35.68\%), whereas polyphenol and ascorbic acid showed maximum enhancement of 77.1 and $139.8 \%$, respectively. The accumulation of heavy metals was found to be higher in the root than shoot of $S$. robusta with maximum accumulation being $0.053 \mathrm{mg} / \mathrm{g}$ in root for $\mathrm{Cd}, 0.17 \mathrm{mg} / \mathrm{g}$ of As in leaf and, $0.201 \mathrm{mg} / \mathrm{g}$ of $\mathrm{Pb}$ in soil. Concentration- dependent changes were observed in most of the morphological and biochemical parameters, which may thus serve to determine suitable bio-indicators of heavy metal pollution.
\end{abstract}

Key words: Shorea robusta, biochemical indicator, heavy metals, accumulation, toxicity.

\section{Introduction}

Environment Pollution is one of the severe problems faced by the world today. Various efforts have been made for environmental conservation in India, but it still seems to be a formidable task. The term 'heavy metal' refers to any metallic element that has a relatively high density and is toxic or poisonous even at low concentration (Lenntech, 2004). Heavy metal is a general collective term, which applies to the group of metals and metalloids with atomic density greater than $4 \mathrm{~g} / \mathrm{cm}^{3}$ or five times or more, than water (Garbarino et al., 1995; Hawkes, 1997). Toxic metals are biologically magnified through the food chain. They infect the environment by affecting soil properties its fertility, biomass and crop yields, and ultimately human health. Heavy metals are major environmental pollutant, which are originate from activities, mostly industrial wastes (Weisberg et al., 2003). Their accumulation in soil becomes dangerous to all kind of organisms including plants (Gichner et al., 2006). Cadmium, being a highly toxic metal pollutant of soils, inhibits root and shoot growth and yield production, affects nutrient 
uptake and homeostasis, is frequently accumulated by agriculturally important crops and then enters the food chain with a significant potential to impair animal and human health (di Toppi, Gabrielli, 1999). Cadmium ranks the highest among all toxic metals in terms of damage to plant growth and human health. Moreover, its uptake and accumulation in plants poses a serious health threat to humans via the food chain (Shah, Dubey, 1998). The presence of excessive amount of $\mathrm{Cd}$ in soil commonly results in many stress symptoms in plants, such as reduction growth, especially roots growth, disturbance in mineral nutrition and carbohydrate metabolism (Moya et al., 1993) and may thus reduce biomass production. Lead is one of the most abundant metals in the earth's crust. Exposure to lead in the environmental and occupational setting continues to be a serious health problem (WHO, 1995). Elevated lead in soil may lessen productivity and even a very low concentration can inhibit some vital plant processes, such as seed germination, photosynthesis, mitosis, plant water status, mineral nutrition and enzymatic activities (Patra et al., 2004).

Lead is a potentially toxic heavy metal with characteristic toxic action and is the main source of environmental pollution. It inhibits some metabolic activities in the plants such as the biosynthesis of nitrogenous compounds, carbohydrate metabolism and water absorption (Sharma, Dubey, 2005; Hamid et al., 2010). Pb contamination in soils not only induced changes in soil microorganisms and their activities resulted in soil fertility deterioration but also directly affected the change of physiological indices and, furthermore, resulted in yield decline (Majer et al., 2002). Certain plants absorb these toxic metals and help to clean them up from the soil. These plants are called hyper-accumulators. They plants have been shown to be resistant to heavy metals and are capable of accumulating them into their roots and leaves. Thus, biologically engineered methods are designed to improve the use of plants to reduce the amount of heavy metals in contaminated soil. (Mudgal et al., 2010). The present experiment was undertaken to investigate changes in the level of growth, and biochemical parameters in S. robusta treated with $\mathrm{Cd}$, As and $\mathrm{Pb}$ and their accumulation in soil and plant in order to contribute to an understanding of S. robusta adaptation to environmental stress.

\section{Materials and methods}

All the nursery and laboratory studies were carried out at the campus of Forest Research Institute (FRI), Dehradun. In this analysis, seeds were sown directly in the media-filled pots. After germination, the seeds were transferred to the root trainers. The species was placed in the natural condition of central nursery. After 3 weeks, the plants were transferred to polythene bags filled with sand, soil and farmland manure (1:1:1) and irrigated daily. Heavy metal treatment consisted of $\mathrm{CdCl}_{2}, \mathrm{As}_{2} \mathrm{O}_{3}$ and $\mathrm{Pb}\left(\mathrm{C}_{2} \mathrm{H}_{3} \mathrm{O}_{2}\right) \cdot 3 \mathrm{H}_{2} \mathrm{O}$, each with three different concentrations of 1 $\mathrm{mg} / \mathrm{l}, 5 \mathrm{mg} / \mathrm{l}$ and $10 \mathrm{mg} / \mathrm{l}$. The treatment was given to the plants for 4 months. Three replicates of each plant along with control were taken. After completion of the treatment (4 months), the plants were removed from polythene bags and their parts (root, shoot and leaf) separated. These parts were analysed for morphological and biochemical parameters for heavy metals concentration. Soil samples were also analysed for heavy metal concentration. All the biochemical parameters were estimated by using spectrophotometer (UV 2700).

Leaf area: Leaves at all the positions in the plants were taken. At the end of the experimental period, the leaf area was measured in $\mathrm{cm}^{2}$ using the leaf area meter Delta-T Device (Buewell Cambridge England) at the end of the experimental period. (Potter et al., 1996).

Root and Shoot length: Root and Shoot length $(\mathrm{cm})$ were measured with the help of metre scale for each individual plant (Dittmer,1959).

Chlorophyll: Chlorophyll in leaves was estimated by Arnon (1945) method. Fresh leaf samples were homogenised in $80 \%$ acetone and optical densities were measured at 645 and $663 \mathrm{~nm}$ with spectrophotometer (Spectra scan UV 2700). 
Protein: Protein content (mg/g) was estimated by the procedure given by Lowry et al. (1951).

Free Amino Acid: Free amino acid (mg/g) was measured by the ninhydrin method given by Moore and Stein (1948). Absorbance was recorded at $570 \mathrm{~nm}$ using a spectrophotometer (Spectrascan UV 2700).

Ascorbic acid estimation: Fresh leaf sample $(0.5 \mathrm{~g})$ was homogenised in $20 \mathrm{ml}$ of extracting media of $0.5 \mathrm{~g}$ oxalic acid and $0.075 \mathrm{~g}$ EDTA in $100 \mathrm{ml}$ distilled water. After centrifuging the homogenate for $15 \mathrm{~min}, 1.0 \mathrm{ml}$ of the homogenate was mixed with $5.0 \mathrm{ml}$ of Dichlorophenol indophenols $(20 \mu \mathrm{g} / \mathrm{ml})$. After shaking well, its optical density was measured at $520 \mathrm{~nm}$ (Sadasivam, Balasubramaniam, 1987) and value presented as $\mathrm{mg} / \mathrm{g}$.

Polyphenol estimation: Polyphenol estimation was done by the method given by Schandari (1970). About $0.5 \mathrm{~g}$ of powdered sample of $S$. robusta leaves were boiled with distilled water for $30 \mathrm{~min}$. Volume of the supernatant was made up to $100 \mathrm{ml}$ by adding distilled water. Folin Denis reagent and sodium carbonate solution were added in known aliquots and absorbance was read at $700 \mathrm{~nm}$ after $30 \mathrm{~min}$. Values of polyphenol were presented as $\%$.

Estimation of heavy metals

Air-dried samples (soil and root, shoot leafs of S. robusta) were ground and sieved. $0.2 \mathrm{~g}$ of plant samples were digested using nitric acid and parchloric acid. Filtrate was analysed with atomic absorption spectrophotometer (AAS) and inductively coupled plasma mass spectrophotometer (ICPMS) as outlined by Wang et al. (1999).

Statistical analysis

The data were analysed using the SPSS program for windows version 15.0. Multiple comparisons and two- way analysis of variance (ANOVA) procedures were used to compare the differences among the treatments. The least significant difference (LSD) tests were performed to determine the significance of treatment means at $P<0.05$.

\section{Results and discussion}

The data incorporated in Table 1 display that the results obtained from the present study showed that after cadmium treatments $(1,5$ and $10 \mathrm{mg} / \mathrm{l})$, S. robusta plant exhibits the reduction in root length at all concentration over control. At cadmium treatment, maximum decrease of $26.25 \%$ in root length was observed at $10 \mathrm{mg} / \mathrm{l}$ treatment, followed by $18.75 \%$ at $5 \mathrm{mg} / \mathrm{l}$ and $8.75 \%$ at $10 \mathrm{mg} / \mathrm{l}$ treatment of heavy metal. The obtained data of shoot length showed that maximum reduction of $18.18 \%$ was observed at $10 \mathrm{mg} / \mathrm{l}$ doses and minimum at $5 \mathrm{mg} / \mathrm{l}(13.63 \%)$. For leaf area more reduction was found at $10 \mathrm{mg} / \mathrm{l}(72.72 \%)$ and minimum at $1 \mathrm{mg} / \mathrm{l}(63.69 \%)$.

The investigation revealed significant reduction $(P<0.001)$ in chlorophyll content for $S$. robusta seedling. A concentration dependent decrease in chlorophyll content over control was observed in the leaves. After Cd treatment maximum reduction of $63.72 \%$ was observed at $10 \mathrm{mg} / \mathrm{l}$ and minimum at $1 \mathrm{mg} / \mathrm{l}(25.4 \%)$. For protein, higher reduction was found at 10 $\mathrm{mg} / \mathrm{l}(35.68 \%)$ and lower at $1 \mathrm{mg} / \mathrm{l}(15.0 \%)$. A gradual decrease in amino acid with increasing concentrations of metals was observed over control $(P<0.001)$. Maximum decrease in amino acid was observed in $10 \mathrm{mg} / \mathrm{l}$ treatment (64.94\%) and minimum in $1 \mathrm{mg} / \mathrm{l}$ treatment $(23.01 \%)$. As observed, at $10 \mathrm{mg} / \mathrm{l}$ treatment of cadmium, maximum enhancement in ascorbic acid was $98.4 \%$ and minimum was $36.5 \%$ in $1 \mathrm{mg} / \mathrm{l}$ treatment. The results indicated that the increase of polyphenol was dependent on the concentration of heavy metals. A concentration-dependent increase in polyphenol content was observed $(P<0.001)$. After cadmium treatment, the maximum enhancement in polyphenol content was observed in $10 \mathrm{mg} / \mathrm{l}(40.7 \%)$ and minimum was in $5 \mathrm{mg} / \mathrm{l}(37.2 \%)$ (Table 1$)$.

After arsenic treatment the species $S$. robusta exhibits reduction in root length at all concentrations over control (Table 1). Maximum decrease in root length was found at 10 $\mathrm{mg} / \mathrm{l}$ treatment $(25.25 \%)$ and slight enhancement of $0.0004 \%$ at $1 \mathrm{mg} / \mathrm{l}$ treatment. For shoot length, $54 \%$ reduction was found in $10 \mathrm{mg} / \mathrm{l}$ while increase in shoot length was found in 1 
T a b le 1. Data showing morphological and biochemical changes of Shorea robusta seedling plants.

\begin{tabular}{|c|c|c|c|}
\hline \multirow[t]{2}{*}{ Treatments(mg/l) } & \multicolumn{3}{|c|}{ Metals } \\
\hline & Cd & As & $\mathbf{P b}$ \\
\hline \multicolumn{4}{|c|}{ Root length $\left(\mathrm{Cm}^{2}\right)$} \\
\hline Control & $40.0 \pm 2.887$ & $26.0 \pm 2.309$ & $33.0 \pm 5.196$ \\
\hline 1 & $36.5 \pm 2.021$ & $27.0 \pm 2.887$ & $39.5 \pm 1.443$ \\
\hline 5 & $32.5 \pm 4.330$ & $23.5 \pm 1.443$ & $23.5 \pm 2.598$ \\
\hline 10 & $29.5 \pm 2.598$ & $19.5 \pm 0.289$ & $27.5 \pm 1.443$ \\
\hline \multicolumn{4}{|c|}{ Shoot length $\left(\mathrm{Cm}^{2}\right)$} \\
\hline Control & $44.0 \pm 4.041$ & $25.0 \pm 0.577$ & $42.3 \pm 7.263$ \\
\hline 1 & $37.0 \pm 5.196$ & $27.0 \pm 5.774$ & $36.00 \pm 3.464$ \\
\hline 5 & $38.0 \pm 4.041$ & $26.0 \pm 5.774$ & $29.500 \pm 1.443$ \\
\hline 10 & $36.0 \pm 9.815$ & $11.5 \pm 0.289$ & $26.50 \pm 2.598$ \\
\hline \multicolumn{4}{|c|}{ Leaf area $\left(\mathrm{Cm}^{2}\right)$} \\
\hline Control & $2361.37 \pm 95.79$ & $1449.32 \pm 220.20$ & $1525.0 \pm 176.09$ \\
\hline 1 & $857.18 \pm 270.25$ & $1082.60 \pm 110.10$ & $942.50 \pm 07.22$ \\
\hline 5 & $852.50 \pm 59.06$ & $106.44 \pm 20.48$ & $1433.60 \pm 0.17$ \\
\hline 10 & $644.12 \pm 0.030$ & $305.22 \pm 18.26$ & $1308.72 \pm 188.9$ \\
\hline \multicolumn{4}{|c|}{ Total chlorophyll $(\mathrm{mg} / \mathrm{g})$} \\
\hline Control & $0.295 \pm 0.003$ & $0.295 \pm 0.003$ & $0.300 \pm 0.006$ \\
\hline 1 & $0.220 \pm 0.006$ & $0.230 \pm 0.006$ & $0.243 \pm 0.009$ \\
\hline 5 & $0.167 \pm 0.017$ & $0.180 \pm 0.006$ & $0.170 \pm 0.006$ \\
\hline 10 & $0.107 \pm 0.007$ & $0.140 \pm 0.012$ & $0.095 \pm 0.003$ \\
\hline \multicolumn{4}{|c|}{ Protein $(\mathrm{mg} / \mathrm{g})$} \\
\hline Control & $51.23 \pm 0.006$ & $48.33 \pm 0.009$ & $32.95 \pm 0.006$ \\
\hline 1 & $43.52 \pm 0.006$ & $40.74 \pm 0.006$ & $38.72 \pm 0.006$ \\
\hline 5 & $42.20 \pm 0.006$ & $38.72 \pm 0.006$ & $41.32 \pm 0.003$ \\
\hline 10 & $32.95 \pm 0.006$ & $32.34 \pm 0.361$ & $46.71 \pm 1.943$ \\
\hline \multicolumn{4}{|c|}{ Total free amino acid $(\mathrm{mg} / \mathrm{g})$} \\
\hline Control & $4.650 \pm 0.673$ & $5.430 \pm 0.035$ & $5.271 \pm 0.001$ \\
\hline 1 & $3.580 \pm 0.098$ & $3.315 \pm 0.001$ & $3.245 \pm 0.020$ \\
\hline 5 & $2.140 \pm 0.017$ & $2.140 \pm 0.017$ & $2.335 \pm 0.014$ \\
\hline 10 & $1.630 \pm 0.006$ & $1.350 \pm 0.017$ & $1.525 \pm 0.009$ \\
\hline \multicolumn{4}{|c|}{ Ascorbic acid (mg/g) } \\
\hline Control & $2.000 \pm 0.104$ & $1.820 \pm 0.003$ & $2.000 \pm 0.104$ \\
\hline 1 & $2.730 \pm 0.104$ & $3.185 \pm 0.055$ & $4.190 \pm 0.104$ \\
\hline 5 & $3.915 \pm 0.159$ & $2.365 \pm 0.107$ & $3.640 \pm 0.002$ \\
\hline 10 & $3.368 \pm 0.579$ & $4.365 \pm 0.003$ & $4.360 \pm 0.006$ \\
\hline \multicolumn{4}{|c|}{ Polyphenol (\%) } \\
\hline Control & $2.580 \pm 0.017$ & $2.050 \pm 0.035$ & $2.325 \pm 0.009$ \\
\hline 1 & $3.590 \pm 0.007$ & $3.310 \pm 0.003$ & $3.420 \pm 0.087$ \\
\hline 5 & $3.540 \pm 0.017$ & $2.860 \pm 0.006$ & $2.900 \pm 0.017$ \\
\hline 10 & $3.630 \pm 0.007$ & $3.630 \pm 0.003$ & $3.590 \pm 0.006$ \\
\hline
\end{tabular}

Values expressed are means \pm standard deviation of three separate experiments. 
$\mathrm{mg} / \mathrm{l}$ and $5 \mathrm{mg} / \mathrm{l}$ doses as compared to the control value. Maximum reduction in leaf area (compared to control) was found in $5 \mathrm{mg} / \mathrm{l}$ treatment (92.67\%) and lower in $1 \mathrm{mg} / \mathrm{l}$ (25.3\%).

Species seedling when treated with arsenic treatment exhibited reduction in total chlorophyll content at all concentration over control (Table 1). After treatment more reduction was observed in $10 \mathrm{mg} / \mathrm{l}$ (52.54\%) and less in $1 \mathrm{mg} / \mathrm{l}$ (22.03\%). Arsenic exhibited reduction in protein content at all concentration, and maximum reduction of $33.09 \%$ was observed in $10 \mathrm{mg} / \mathrm{l}$ doses and minimum in $1 \mathrm{mg} / \mathrm{l}(15.70 \%)$ doses. Reduction in free amino acid content was found in $10 \mathrm{mg} / \mathrm{l}$ treatment that was $75.13 \%$ and minimum in $1 \mathrm{mg} / \mathrm{l}(38.95 \%)$. It was observed that in ascorbic acid, maximum enhancement was found in $10 \mathrm{mg} / \mathrm{l}(139.8 \%)$ and minimum was in $1 \mathrm{mg} / \mathrm{l}(75 \%)$. A concentration-dependent increase in polyphenol content was observed. Higher reduction $(77.1 \%)$ was observed at $10 \mathrm{mg} / \mathrm{l}$ dose, and the reduction was lower at $1 \mathrm{mg} / \mathrm{l}(61.46 \%)$ treatments. Species treated with $\mathrm{Pb}$ exhibited reduction in root length at $1 \mathrm{mg} / \mathrm{l}$ and $5 \mathrm{mg} / \mathrm{l}$ concentration over control while at $10 \mathrm{mg} / \mathrm{l}$ treatment increase in root length was observed that was $28.78 \%$. For shoot length, maximum reduction was found in $10 \mathrm{mg} / \mathrm{l}(37.35 \%)$ and minimum in $1 \mathrm{mg} / \mathrm{l}$ treatment $(14.82 \%)$. The percent reduction in leaf area was higher at $1 \mathrm{mg} / \mathrm{l}(38.19 \%)$ treatment.

Species seedling when supplied with lead condition exhibited reduction in total chlorophyll content at all concentration over control. As observed, maximum reduction was observed in $10 \mathrm{mg} / \mathrm{l}(68.33 \%)$ treatment and minimum in $1 \mathrm{mg} / \mathrm{l}(19 \%)$. The species revealed maximum loss of protein content when supplied with lead treatments. Enhancement of $41.76 \%$ was observed in $10 \mathrm{mg} / \mathrm{l}$ treatment. For amino acid, maximum reduction was observed in $10 \mathrm{mg} / \mathrm{l}(71.06 \%)$ and minimum in $1 \mathrm{mg} / \mathrm{l}$ (38.43\%). The enhancement in ascorbic acid was found in different concentration of heavy metals, maximum enhancement was found in $10 \mathrm{mg} / \mathrm{l}(118 \%)$ treatments and minimum enhancement was in $5 \mathrm{mg} / \mathrm{l}$ treatments that was $82 \%$. After lead treatment, $10 \mathrm{mg} / \mathrm{l}$ (54.4\%) exhibited maximum enhancement in polyphenol content and minimum in $5 \mathrm{mg} / \mathrm{l}$ (24.7\%) (Table 1).

Correlation coefficient calculated (Table 3) for morphological and biochemical parameters, metals and treatment showed that the correlation between amino acid and chlorophyll $\left(r^{2}=0.927, P<0.001\right)$ and leaf area with root length $\left(r^{2}=0.418, P<0.05\right)$, chlorophyll $\left(r^{2}\right.$ $=0.509, P<0.05)$ and protein $\left(r^{2}=0.556, P<0.05\right)$.were significantly and positively correlated. Significant negative correlation was found between polyphenol and chlorophyll $\left(r^{2}\right.$ $=-0.746, P<0.001)$ and amino acid $\left(r^{2}=-0.782, P<0.001\right)$ and ascorbic acid $\left(r^{2}=-0.774, P\right.$ $<0.05)$. Ascorbic acid showed negative correlation with chlorophyll $\left(r^{2}=-0.704, P<0.01\right)$ and amino acid $\left(r^{2}=-0.747, P<0.01\right)$ and positive correlation with treatment $\left(r^{2}=0.640, P\right.$ $<0.01)$. Amino acid negatively correlated with treatment $\left(r^{2}=-0.873, P<0.001\right)$ but revealed significant positive correlation between chlorophyll $\left(r^{2}=0.927, P<0.001\right)$ and leaf area $\left(r^{2}=\right.$ $0.584, P<0.05)$. The given results indicate that in the positive correlation if one variable increases another will also increased, and in negative correlation if one variable will increased and another will decreased.

Results indicate that heavy metals affect the morphological and biochemical parameters of Shorea robusta leaves with increasing concentration of metals. Lead and cadmium toxicity have become important due to their constant increase in the environment (Muhamad et al., 2008). The results obtained from this study indicate that excess of heavy metal causes a va- 
T a b l e 2. Accumulations of heavy metal in soil, root, shoot and leaf of Shorea robusta seedling plants.

\begin{tabular}{|c|c|c|c|}
\hline \multicolumn{4}{|c|}{ Shorea robusta } \\
\hline Soil (mg/g) & Cd & As & $\mathrm{Pb}$ \\
\hline Control & ND & ND & ND \\
\hline $1 \mathrm{mg} / \mathrm{l}$ & $0.0092 \pm \mathbf{0 . 0 0 1}$ & $0.0111 \pm \mathbf{0 . 0 0 0 1}$ & $0.0165 \pm \mathbf{0 . 0 0 1}$ \\
\hline $5 \mathrm{mg} / \mathrm{l}$ & $0.0218 \pm \mathbf{0 . 0 0 0 3}$ & $0.0339 \pm \mathbf{0 . 0 0 1 2}$ & $0.1136 \pm \mathbf{0 . 0 4 1}$ \\
\hline $10 \mathrm{mg} / \mathrm{l}$ & $0.0367 \pm \mathbf{0 . 0 0 8 4}$ & $0.066 \pm \mathbf{0 . 0 0 0 1}$ & $0.201 \pm \mathbf{0 . 0 8 8}$ \\
\hline \multicolumn{4}{|l|}{ Root (mg/g) } \\
\hline Control & ND & ND & ND \\
\hline $1 \mathrm{mg} / \mathrm{l}$ & $0.0098 \pm \mathbf{0 . 0 0 0 1}$ & $0.022 \pm \mathbf{0 . 0 0 1}$ & $0.014 \pm \mathbf{0 . 0 0 0 1}$ \\
\hline $5 \mathrm{mg} / \mathrm{l}$ & $0.023 \pm \mathbf{0 . 0 0 0 7}$ & $0.076 \pm \mathbf{0 . 0 0 1}$ & $0.065 \pm \mathbf{0 . 0 2 9}$ \\
\hline $10 \mathrm{mg} / \mathrm{l}$ & $0.053 \pm \mathbf{0 . 0 1 4}$ & $0.056 \pm \mathbf{0 . 0 0 0 1}$ & $0.035 \pm \mathbf{0 . 0 0 2 4}$ \\
\hline \multicolumn{4}{|l|}{ Shoot (mg/g) } \\
\hline Control & ND & ND & ND \\
\hline $1 \mathrm{mg} / \mathrm{l}$ & $0.0084 \pm \mathbf{0 . 0 0 0 2 4}$ & $0.024 \pm \mathbf{0 . 0 0 2}$ & $0.014 \pm \mathbf{0 . 0 0 0 1}$ \\
\hline $5 \mathrm{mg} / \mathrm{l}$ & $0.0019 \pm \mathbf{0 . 0 0 0 1}$ & $0.078 \pm \mathbf{0 . 0 0 0 2}$ & $0.055 \pm \mathbf{0 . 0 0 2}$ \\
\hline $10 \mathrm{mg} / \mathrm{l}$ & $0.0044 \pm \mathbf{0 . 0 0 1 1}$ & $0.141 \pm 0.0002$ & $0.0254 \pm \mathbf{0 . 0 0 4 3}$ \\
\hline \multicolumn{4}{|l|}{ Leaf $(\mathrm{mg} / \mathrm{g})$} \\
\hline Control & ND & ND & ND \\
\hline $1 \mathrm{mg} / \mathrm{l}$ & $0.0082 \pm \mathbf{0 . 0 0 0 1 6}$ & $0.031 \pm \mathbf{0 . 0 0 0 3}$ & $0.014 \pm \mathbf{0 . 0 0 0 4}$ \\
\hline $5 \mathrm{mg} / 1$ & $0.0011 \pm \mathbf{0 . 0 0 0 3 5}$ & $0.090 \pm \mathbf{0 . 0 1}$ & $0.089 \pm \mathbf{0 . 0 0 1}$ \\
\hline $10 \mathrm{mg} / \mathrm{l}$ & $0.0018 \pm \mathbf{0 . 0 0 0 1 3}$ & $0.178 \pm \mathbf{0 . 0 0 1}$ & $0.038 \pm \mathbf{0 . 0 0 5}$ \\
\hline
\end{tabular}

Values expressed are means \pm standard deviation of three separate experiments.

$\mathrm{T}$ a b l e 3. Correlation coefficient ' $r$ ' between morphological and biochemical parameters, metals and treatment of S. robusta.

\begin{tabular}{|c|c|c|c|c|c|c|c|c|}
\hline & Leaf area & $\begin{array}{c}\text { Root } \\
\text { length }\end{array}$ & $\begin{array}{c}\text { Shoot } \\
\text { length }\end{array}$ & $\begin{array}{c}\text { Chloro- } \\
\text { phyll }\end{array}$ & Protein & $\begin{array}{c}\text { Amino } \\
\text { acid }\end{array}$ & $\begin{array}{c}\text { Ascorbic } \\
\text { acid }\end{array}$ & $\begin{array}{c}\text { Polyphe- } \\
\text { nol }\end{array}$ \\
\hline Metal & 0.080 & -0.207 & -0.099 & 0.029 & -0.176 & 0.027 & 0.233 & -0.210 \\
\hline Treatment & $-0.473^{*}$ & 0.013 & -0.082 & $-0.933^{* * *}$ & -0.374 & $-0.873^{* * *}$ & $0.640^{* *}$ & $0.615^{* *}$ \\
\hline Leaf area & 1.00 & $0.418^{*}$ & 0.294 & $0.509^{*}$ & $0.556^{*}$ & $0.584^{*}$ & -0.357 & -0.490 \\
\hline Root length & $0.418^{*}$ & 1.00 & $0.426^{*}$ & 0.010 & 0.297 & 0.083 & -0.160 & 0.046 \\
\hline Shoot ength & 0.294 & $0.426^{*}$ & 1.00 & 0.052 & -0.051 & 0.100 & -0.088 & 0.044 \\
\hline Chlorophyll & $0.509^{*}$ & 0.010 & 0.052 & 1.00 & 0.300 & $0.927^{* * *}$ & $-0.704^{* *}$ & $-0.746^{* * *}$ \\
\hline Protein & $0.556^{*}$ & 0.297 & -0.051 & 0.300 & 1.00 & 0.349 & -0.267 & -0.296 \\
\hline Amino acid & $0.584^{*}$ & 0.083 & 0.100 & $0.927^{* * *}$ & 0.349 & 1.00 & $-0.747^{* * *}$ & $-0.782^{* * *}$ \\
\hline Ascorbic acid & -0.357 & -0.160 & -0.088 & $-0.704^{* *}$ & -0.267 & $-0.747^{* * *}$ & 1.00 & $0.774^{* * *}$ \\
\hline Polyphenol & -0.490 & 0.046 & 0.044 & $-0.746^{* * *}$ & -0.296 & $-0.782^{* * *}$ & $0.774^{* * *}$ & 1.00 \\
\hline
\end{tabular}

* - significance at $0.05,{ }^{* *}$ - significance at $0.01,{ }^{* *}$ - significance at 0.001

riety of toxicity symptoms in plants, such as reduced growth. According to Eun et al. (2000) the reduction in plant growth during stress is due to low water potential, hampered nutrient uptake and secondary stress such as oxidative stress. The effect of treatments was more 
pronounced in case of root length. Roots are more prone to heavy metal toxicity relative to shoots (Oncel et al., 2000).

The higher impact of heavy metal was observed in the root growth as compared to shoot leading to a reduction in its length and fresh weight (Elloumi et al., 2007). The reduction in root length due to accumulation of metals within the root reduces the rate of mitosis in the meristematic zones of roots, especially by blocking the metaphase in meristemetic cells. Therefore, root showed reduction in length as demonstrated by Pant et al. (2011). Root is capable of accumulating significant quantities of this heavy metal and simultaneously restricts its translocation to the shoot. Retarded shoot length due to the presence of the root environment with excess of $\mathrm{Pb}$ has been found by Seyyedi (1999). The decrease in shoot length and biomass with increasing concentration of heavy metals may be due to the sensitivity of enzymes of the photosynthetic carbon reduction cycle to cadmium, as reported by De Filippis and Ziegler (1993). Tripathi and Tripathi (1999), reported similar results in an experiment where 1, 5 and 10ppm of $\mathrm{Cr}, \mathrm{Ni}$ and $\mathrm{Hg}$ affected the leaf area and root and shoot length of Albizia lebbek. Our results are in agreement with the findings of Tandy et al. (2006), for Helianthus annuus growing in nutrient solution with $\mathrm{Pb}$ and Guo et al. (2007).

Chlorophyll is essential for photosynthesis and is very sensitive to environmental stress such as heavy metals (Ekmekci et al., 2008). Plant exposed to Pb ions showed a considerable decrease in their dry weight and a decline in the total chlorophyll and thus photosynthetic efficiency (Kambhampati et al., 2005). The plant processes are adversely affected by the increasing $\mathrm{Pb}$ levels in soil and even at very low concentration (Patra et al., 2004). The present study shows that cadmium, arsenic and lead are toxic to species as shown by the toxicity symptoms, such as chlorosis, decrease in the biomass and total chlorophyll content, developed in plants. Our results for decrease in chlorophyll content are corroborated with the findings of Siedlecka and Krupa (1996) who have also found a decrease in chlorophyll content with heavy metal stress in Zea mays and Acer rubrum. Similar results have been previously reported for sunflower (Zengin, Munzuruglu, 2005), almond (Elloumi et al., 2007), Casia fistula (Pandey et al., 2011) and other researchers (Wang et al., 2009; John et al., 2009; Mobin, Khan, 2007). Phetsombat (2006) also reported similar finding in Salvinia cucullata. The presence of Cd decreased the content of chlorophyll and carotenoids, and increased nonphotochemical quenching in Brassica napus as observed by Larsen et al. (1998). A considerable loss in total chlorophyll in the plants treated with heavy metal was confirmed by Tripathi and Tripathi (1998) and Hemalatha et al. (1997).

Proteins are important constituents of the cell that are easily damaged in environmental stress condition. Hence, any change in these compounds can be considered an important indicator of oxidative stress in plants. The results of this study showed varied changes in protein content in leaf after different metal treatments. It has been reported that $\mathrm{Cd}$, As and $\mathrm{Pb}$ are able to decrease protein content by inhibiting the uptake of $\mathrm{Mg}$ and $\mathrm{K}$ ions and promote postranslational modification (Gardea Torresday et al., 2004; Romero-Puertas et al., 2007), decrease in synthesis or increase in protein degradation (Monterio et al., 2009) and the prevention of rubisco activity (Muthuchelian et al., 2001; Siedlecka, Krupa, 1996). Heavy metals reduced soluble proteins in agricultural crops and in this study the effect was much pronounced on forestry tree species as compared to agricultural crops (Hemalatha et al., 
1997). Tripathi and Tripathi (1998) worked on Albizia lebbek for $\mathrm{Hg}$, Cr and Ni treatments. The study of protein content coincides with the findings of Singh and Sinha (2005) who also found decrease in protein content in $B$. juncea when grown on various amendments of tannery waste containing heavy metals. The increase in protein under heavy metal stress may be related to induce the synthesis of stress protein such as enzymes involved in Krebs cycle, glutathione and phytochelation biosynthesis and some heat shock proteins (Verma, Dubay, 2003; Mishra et al., 2006).

Amino acids play a central role in plant primary metabolism. Previous studies indicated that decrease in the mitochondrial electron transport activity accompanies increase in proline accumulation under heavy metal stress (Saradhi et al., 1995). The induction of proline accumulation in response to abiotic stress may be due to increase in its de novo synthesis or decreased degradation (Kasai et al., 1998), and the effect of proline on the permeability of membrane (Pesci, Reggiani, 1992). Therefore, the increase of proline can be considered as an indicator of tolerance of heavy metal stress.

Polyphenol occurs in all plant parts and offers resistance against diseases and pests. In this study, polyphenol content gradually increased in some plants with the increasing concentrations of heavy metals. It has been found that polyphenols concentration can alter with the altered natural environmental conditions, and increases in the tissues surrounding a wound. Similar results were observed by Tripathi and Tripathi (1998) in Albizia lebbek. Antioxidants like systeine, proline, ascorbic acid and nonprotein thiol (sulfhydryl) play an important role in detoxification of toxic metal ions (Singh, Sinha, 2005).

Table 2 shows the concentration of heavy metals in soil and different plant parts (root, shoot, leaf). At $10 \mathrm{mg} / \mathrm{l}$ treatment, the maximum concentration of cadmium was detected in the root $(0.053 \pm 0.014 \mathrm{mg} / \mathrm{g})$ followed by soil $(0.0367 \pm 0.0084 \mathrm{mg} / \mathrm{g})$ and shoot $(0.0044 \pm$ $0.0011 \mathrm{mg} / \mathrm{g})$ and least in leaves $(0.0018 \pm 0.00013 \mathrm{mg} / \mathrm{g})$. At $5 \mathrm{mg} / \mathrm{l}$ doses, maximum concentration of cadmium was detected in root $(0.023 \pm 0.001 \mathrm{mg} / \mathrm{g})$ and minimum in leaf $(0.0011$ $\pm 0.00003 \mathrm{mg} / \mathrm{g})$. At $1 \mathrm{mg} / \mathrm{l}$ cadmium doses, maximum concentration was detected in root $(0.0098 \pm 0.0001 \mathrm{mg} / \mathrm{g})$ and minimum in leaves $(0.0082 \pm 0.0002 \mathrm{mg} / \mathrm{g})$ (Table 2).

For $10 \mathrm{mg} / \mathrm{l}$ arsenic doses, the maximum concentration was detected in the leaves $(0.178$ $\pm 0.001 \mathrm{mg} / \mathrm{g})$ followed by shoot $(0.141 \pm 0.00002 \mathrm{mg} / \mathrm{g})$, soil $(0.066 \pm 0.0001 \mathrm{mg} / \mathrm{g})$ and least in root $(0.056 \pm 0.0001 \mathrm{mg} / \mathrm{g})$. For $5 \mathrm{mg} / \mathrm{l}$ arsenic doses, maximum concentration was detected in leaves $(0.090 \pm 0.0058 \mathrm{mg} / \mathrm{g})$ and minimum in soil $(0.0339 \pm 0.0012 \mathrm{mg} / \mathrm{g})$. For $1 \mathrm{mg} / \mathrm{l}$ arsenic doses, maximum concentration was detected in leaves $(0.0307 \pm 0.0003 \mathrm{mg} / \mathrm{g})$ and minimum in soil $(0.011 \pm 0.0001 \mathrm{mg} / \mathrm{g})$ (Table 2$)$.

For $10 \mathrm{mg} / \mathrm{l}$ lead doses, the maximum concentration was detected in the soil $(0.201 \pm$ $0.0884 \mathrm{mg} / \mathrm{g})$ followed by leaves $(0.038 \pm 0.0048 \mathrm{mg} / \mathrm{g})$, root $(0.035 \pm 0.0024 \mathrm{mg} / \mathrm{g})$ and least in shoot $(0.0254 \pm 0.0043 \mathrm{mg} / \mathrm{g})$. For $5 \mathrm{mg} / \mathrm{l}$ lead condition, maximum concentration was detected in soil $(0.114 \pm 0.041 \mathrm{mg} / \mathrm{g})$ and minimum in shoot $(0.055 \pm 0.0022 \mathrm{mg} / \mathrm{g})$. For $1 \mathrm{mg} / \mathrm{l}$ doses, maximum concentration of lead was detected in soil $(0.0165 \pm 0.0001 \mathrm{mg} / \mathrm{g})$ and minimum in shoot $(0.0137 \pm 0.00004 \mathrm{mg} / \mathrm{g})$ (Table 2).

The results revealed that under the experimental conditions, the accumulation of heavy metal increased when the exposure time and concentration of metal were increased. The finding of the present study of heavy metal accumulation in soil and different plant parts 
coincides with those of Pandey and Tripathi (2010) in Albizia procera, when the doses of cadmium, arsenic and lead given to the plant seedlings. Similar results were reported by Umebese and Motajo (2008) in Ceratophyllum demersum. At low concentrations, some heavy metals act as micronutrients causing a rapid overall growth of the seedling. However, increasing the concentration of metals above critical level severely inhibits the seedling growth in terms of various morphological and biochemical parameters. From the view of phytoremediation, a good accumulator should have the ability to concentrate the element in the tissue (Rashed, 2010). Once the metals have been concentrated and extracted by the plants, they can be easily removed from the site (Gratao et al., 2005).

\section{Conclusion}

In conclusion, our results indicated that the exposure of $S$. robusta to $\mathrm{Cd}$, As and $\mathrm{Pb}$ resulted in a decrease in root and shoot length, area and pigment content at higher concentration of heavy metals, and increase of Ascorbic acid and polyphenol was observed at higher concentrations. More As was accumulated more than $\mathrm{Cd}$ and $\mathrm{Pb}$ in shoot of S. robusta. Cd and As was more effective than $\mathrm{Pb}$ metals in hampering the plant growth and developemt.

\section{Acknowledgements}

The authors thank Dr D.P. Dobhal, Scientist-C, Wadia Institute Dr P.P. Khanna, Scientist-E, Wadia Institute and Mr M.S. Rawat, for providing help in the analysis of heavy metals.

\section{References}

Ahmad, P., Jhon, R., Sarwat, M. \& Umar S. (2008). Responses of proline, lipid peroxidation and antioxidative enzyme in two varieties of Pisam sativum L. Under salt stress. International Journal of Plant Production, 2, 353-366.

Arnon, D.I. (1949). Copper enzymes in isolated chloroplasts. Polyphenol oxidase in Beta vulgaris. Plant Physiol., 24, 1-15. DOI: 10.1104/pp.24.1.1.

De Filippis, L.F. \& Ziegler H. (1993). Effect of sublethal concentrations of zinc, cadmium and mercury on the photosynthetic carbon reduction cycle of Euglena. J. Plant Physiol., 142, 167-172. DOI: 10.1016/S0176-1617(11)80958-2.

Di Toppi, S.L. \& Gabrielli R. (1999). Response to cadmium in higher plants. Environ. Exp. Bot., 41, 105-130. DOI: 10.1016/S0098-8472(98)00058-6.

Dittmer, H.J. (1959). A method to determine the length of individual roots. Bulletin of the Torrey Botanical Club, 86, 59-61. http://www.jstor.org/stable/2482661

Ekmekci, Y., Tanyolac, D. \& Ayhan R. (2008). Effect of cadmium on antioxidant enzyme and photosynthetic activities in leaves of two maize cultivars. J. Plant Physiol., 165, 600-611. DOI: 10.1016/j.jplph.2007.01.017.

Elloumi, N., Ben, F., Rhouma, A., Ben, B., Mezghani. I. and Boukhris, M., 2007. Cadmium induced growth inhibition and alteration of biochemical parameters of almond seedling grown in solution culture. Acta Physiol. Plant., 29, 57-62. DOI: 10.1007/s11738-006-0009-y.

Eun, S.O., Youn, H.S. \& Lee Y. (2000). Lead disturbs microtubule organization in the root meristem of Zea mays. Physiol. Plant., 110(3), 357-365. DOI: 10.1111/j.1399-3054.2000.1100310.x.

Garbarino, J.R., Hayes, H., Roth, D., Antweider, R., Brinton, T.I. \& Taylar H. (1995). Contaminants in the Mississippi river. U.S. Geological Survey Circular 1133. Virginia.

Gardea Torresday, J.L., Peralta-Videa, J.R., Montes, M., de la Rosa, G. \& Corral- Diaz B. (2004). Bioaccumulation of cadmium, chromium and copper by Convolvulus arvensis L.: impact on plant growth and uptake of nutritional element. Bioresour. Technol., 92, 229-235. DOI: 10.1016/j.biortech.2003.10.002.

Gichner, T., Patkova, Z., Szakova, J. \& Demnerrova K. (2006). Toxicity and DNA damage in tobacco and potato palnt growing on soil polluted with heavy metals. Ecotoxicol. Environ. Saf., 65, 420-426. DOI: 10.1016/j.ecoenv.2005.08.006. 
Gratao, P.L., Prasad, M.N.V., Cardoso, P.F., Lea, P.J. \& Azevedo R.A. (2005). Phytoremediation: green technology for the cleanup of toxic metals in the environment. Brazilian Journal of Plant Physiology, 17(1), 53-64. DOI: $10.1590 /$ S1677-04202005000100005.

Guo, T.R., Zhang, G.P. \& Zhang Y.H. (2007). Physiological changes in barley plant under combined toxicity of aluminum, copper and cadmium. Colloids Surface B, 57, 182-188. DOI: 10.1016/j.colsurfb.2007.01.013.

Hamid, N., Bukhari, N. \& Jawaid F. (2010). Physiological responses of Phaseolus vulgaris in different lead concentration. Pak. J. Bot, 42, 239-246.

Hawkes, J.S. (1997). What is a "Heavy Metal". Journal of Chemical Education, 74(11), 1374. DOI: 10.1021/ed074p1374.

Hemalatha, S., Anburaj, A. \& Francis K. (1997). Effect of heavy metals on certain biochemical constituents and nitrate reductase activity in Orzya sativa L. seedlings. J. Environ. Biol., 18, 313-319.

John, P., Ahmad, P., Gadgil, K. \& Sharma S. (2009). Heavy metal toxicity: effect on plant growth, biochemical parameter and metal accumulation by Brassica juncea L. International Journal of Plant Production, 3, 65-76.

Kamphampati, M.S., Begonia, G.B., Begonia, M.F.T. \& Bufford V. (2005). Morphological and Physiological responses of morning glory (Ipomoea lacunusa L.) grown in a lead and chelateanended soil. International Journal of Environmental Research Public Health, 2, 299-303. DOI: 10.3390/ijerph2005020014.

Kasai, Y., Kato, M., Aoyama, J. \& Hyodo H. (1998). Ethylene production and increase in 1-amino-cyclopropane1-carboxylate oxidase activity during senescence of broccoli florets. Acta Horticulturae, 464, 153-157.

Larsen, P.B., Degenhart, J., Stenzler, L.M., Howell, S.H. \& Kochian L.V. (1998). Aluminium-resistant Arabidopsis mutant that exhibit altered pattern of aluminium accumulation and organic acid release from roots. Plant Physiol., 117, 9-18. DOI: 10.1104/pp.117.1.9.

Lenntech water treatment and ait purification (2004). Water treatment. Rotterdamseweg: Lenntech.

Lowry, O.H., Rosebrough, J., Far, A.L. \& Randall R.J. (1951). Protein measurement with Folin- phenol reagent. J. Biol. Chem., 193, 265-275.

Majer, B.J., Tscherko, D. \& Paschke A. (2002). Effects of heavy metal contamination of soils on micronucleus induction in Tradescantia and on microbial enzyme activities: a comparative investigation. Mutation Research, 515, 111-124. DOI: 10.1016/S1383-5718(02)00004-9.

Mishra, S., Srivastava, S., Tripathi, R.D., Kumar, R., Seth, C.S. \& Gupta D.K. (2006). Lead detoxification by coontal (Ceratoxhyllum demersum L.) involves induction of phytochelatins and anti-oxidant system in response to its accumulation. Chemosphere, 65, 1027-1039. DOI: 10.1016/j.chemosphere.2006.03.033.

Mobin, M. \& Khan N.A. (2007). Photosynthetic activity, pigment composition and antioxidative response of two mustard (Brassica juncea) cultivars differing in photosynthetic capacity subjected cadmium stress. J. Plant Physiol., 164, 601-610. DOI: 10.1016/j.jplph.2006.03.003.

Monterio, M.S., Santos, C., Soares, A.M.V.M. \& Mann R.M. (2009). Assessment of biomarkers of cadmium stress in lettuce. Ecotoxicol. Environ. Saf., 72, 811-818. DOI: 10.1016/j.ecoenv.2008.08.002.

Moore, S. \& Stein W.H. (1948). Photometric method for use in the chromatography of amino acid. J. Biol. Chem., $176,367-388$.

Moya, J.L., Ros, R. \& Picazo I. (1993). Influence of cadmium and nickel on growth, net photosynthesis and carbohydrate distribution in rice plants. Photosynth. Res., 36, 75-80. DOI: 10.1007/BF00016271.

Muhamad, S., Iqbal, M.Z. \& Mohammad A. (2008). Effect of Lead and Cadmium on germination and seedling growth of Leucaena leucocephala. Journal of Applied Science and Evironmental Management, 12(3), 61-66.

Muthuchelian, K., Bertamini, M. \& Nedunchezhian N. (2001). Triacontonol can protect Erythrina variegate from cadmium toxicity. J. Plant Physiol., 158, 1487-1490. DOI: 10.1078/0176-1617-00627.

Oncel, I., Keles, Y. \& Ustun A.S. (2000). Interactive effects of temperature and heavy metal stress on the growth and some biochemical compoubd in wheat seedling. Environ. Pollut., 107, 315-320. DOI: 10.1016/S02697491(99)00177-3.

Pandey, P. \& Tripathi A.K. (2010). Bioaccumulation of heavy metal in soil and different plant parts of A. procera (Roxb.) seedling. The Bioscan, 5(2), 263-266.

Pandey, P. \& Tripathi A.K. (2011). Effect of Heavy metals on morphological and Biochemical characteristics of Albizia procera (Roxb. B enth.) seedling. International Journal of Environmental Science, 1(5), 1009-1018.

Pant, P.P., Tripathi, A.K. \& Gairola S. (2011). Phytpremediation of Arsenic using Cassia fistula Lin n. seedling. International Journal of Research in Chemistry and Environment, 1(1), 24-28.

Patra, M., Bhowmik, N., Bandopadhyay, B. \& Sharma A. (2004). Comparison of mercury, lead and arsenic with respect to genotype effects on plant systems and the development of genetic tolerance. Environ. Exp. Bot., 52, 199-223. DOI: 10.1016/j.envexpbot.2004.02.009. 
Pesci, P. \& Reggiani R. (1992). The process of abscisic acid induced proline accumulation and the leves of polyamines and quaternary ammonium compounds in hydrated barley leaves. Physiol. Plant., 84, 134-139. DOI: 10.1111/j.1399-3054.1992.tb08775.x.

Phetsombat, S., Kruatrachue, M., Pokethitiyook, P. \& Upatham S. (2006). Toxicity and bioaccumulation of cadmium and lead in Salvinia cucullata. J. Environ. Biol., 27(4), 645-652.

Potter, E., Wood, J. \& Nicholl C. (1996). Sunscan canopy analysis system: User manual. Cambridge: Delta-T Devices.

Prasad, M.N.V., Malec, A., Waloszek, A., Bojko, M. \& Strzalka K. (2001). Physiological responses of Lemna trisulka L. to cadmium and copper bioaccumulation. Plant Sci., 161, 881-889. DOI: 10.1016/S0168-9452(01)00478-2.

Rashed, M.N. (2010). Monitoring of contaminated toxic and heavy metals, from mine tailings through age accumulation, in soil and some wild plants at Southeast Egypt. J. Hazard. Mater., 178(1-3), 739-746. DOI: 10.1016/j. jhazmat.2010.01.147.

Romero-Puertas, M.C., Corpas, F.J., Rodriguez-Serrano, M., Gomez, M., del Rio, L.A. \& Sandalio L.M. (2007). Differential expression and regulation of antioxidative enzyme by cadmium in pea plants. J. Plant Physiol., 164, 1346-1357. DOI: 10.1016/j.jplph.2006.06.018.

Sadasivam, S. \& Balasubramanian, T. (1987). Practical manual in biochemistry. Coimbatore: Tamil Nadu Agricultural University.

Saradhi, P.P., Alia-Arora, S. \& Prasad, K.V.S.K. (1995). Proline accululation in plants exposed to u V radiation and protect them against UV induced peroxidation. Biochem. Biophys. Res. Commun., 209, 1-5. DOI: 10.1006/ bbrc.1995.1461.

Schandari, S.H. (1970). Method in food analysis. New York: Academic Press.

Seyyedi, M., Timko, M.P. \& Sundqvist C. (1999). Protochlorophylliden POR and chlorophyll formation in the lip I mutant of pea. Physiol. Plant., 106, 344-354. DOI: 10.1034/j.1399-3054.1999.106313.x.

Shah, K. \& Dubey R.S. (1998). A $18 \mathrm{kDa}$ cadmium inducible protein complex from rice: its purification and characterization from rice (Oryza sativa L.) roots tissues. J. Plant Physiol., 152, 448-454. DOI: 10.1016/S01761617(98)80262-9.

Sharma, P. \& Dubey R.S. (2005). Lead toxicity in plant. Brazilian Journal of Plant Physiology, 17, 35-52.

Siedlecka, A. \& Krupa Z. (1996). Interaction between cadmium and iron and its effects on photosynthetic capacity of primary leaves of Phaseolus vulgaris. Plant Physiol. Biochem., 34, 833-841.

Singh, S. \& Sinha S. (2005). Accumulation of metals and its effects in Brassica juncea (L.) Czern. (cv. Rohini) grown on various amendments of tannery waste. Ecotoxicol. Environ. Saf., 62, 118-127. DOI: 10.1016/j. ecoenv.2004.12.026.

Tandy, S., Schulin, R. \& Nowack B. (2006). The influence of EDDS on the uptake of heavy metals in hydroponically grown sunflowers. Chemosphere, 62, 1454-1463. DOI: 10.1016/j.chemosphere.2005.06.005.

Tripathi, A.K. \& Tripathi S. (1998). Changes in some physiological and biochemical characters in Albizia lebbek as bio- indicators of heavy metal toxicity. J. Environ. Biol., 20(2), 93-98.

Umebese, C.E. \& Motajo A.F. (2008). Accumulation, tolerance and impact of aluminium, copper and zinc on growth and nitrate reductase activity of Ceratophyllum demensum (Hornwort). J. Environ. Biol., 29, 197-200.

Verma, S. \& Dubey R.S. (2003). Lead toxicity unduces lipid peroxidation and alters the activities of antioxidant enzymes in growing rice plants. Plant Sci., 164, 645-655. DOI: 10.1016/S0168-9452(03)00022-0.

Wang, H., Wang, P.F. \& Zhang H. (2009). Uses of phosphorus alleviate stress induced by cadmium and zinc in two submerged macrophyte. African Journal of Biotechnology, 8, 2176-2183. DOI: 10.5897/AJB09.325.

Wang, X., Zhuang., Z, Sun, D., Hong, J., Wu, X., Lee, F., Yang, M. \& Leung H. (1999). Trace metal in Traditional Chinese medicine: A preliminary study using ICP-MS for metal determination and As speciation. Atomic Spectroscopy, 20, 86-91.

Weisberg, M., Joseph, P., Hale, B. \& Beyersmann D. (2003). Molecular and cellular mechanism of cadmium carcinogenesis. Toxicology, 192, 95-117. DOI: 10.1016/S0300-483X(03)00305-6.

WHO (1995). Inorganic lead environmental health criteria. 165 World Health Organization, Geneva.

Zengin, F.K. \& Munjuruglu O. (2005). Effect of some heavy metals on content of chlorophyll, proline and some antioxidant chemicals in bean (Pheseolus vulgaris L.) seedling. Acta Biologia Cracoviensia Series Botanica, 47,157-164. 